Ashil: Jurnal Pendidikan Anak Usia Dini

Vol. 1 No. 1, April 2021. e-ISSN: 2776-4117

https://doi.org/10.33367/piaud.v1i1.1621

Journal Ashil

Submitted: $\quad$ Revised:

04-03-2021 20-04-2021

Accepted:

Published:

21-04-2021

24-04-2021

\title{
Implementasi Pembelajaran Nilai Agama Dan Moral Pada Anak Usia 4-5 Tahun Selama Belajar Dari Rumah
}

\author{
Maratus Solekah ${ }^{1}$, Anik Lestariningrum ${ }^{2}$, Linda Dwiyanti ${ }^{3}$ \\ 1PG-PAUD UN PGRI Kediri, ${ }^{2}$ PG-PAUD UN PGRI Kediri, ${ }^{3}$ PG-PAUD UN PGRI Kediri \\ 1maratussolekah200@gmail.com, 2anikl@unpkediri.ac.id, 3lindadwiyanti@unpkediri.ac.id
}

\begin{abstract}
Abstrak
Pendidikan mulai anak usia dini terhambat dengan pandemi yang melanda sehingga harus dilakukan proses pembelajaran dari rumah. Dibutuhkan kolaborasi antara guru dan orang tua dalam peningkatan aspek perkembangan anak juga salah satunya terkait pembiasaan penanaman nilai agama moral. Permasalahan yang dihadapi tidak semua orang tua mendukung dalam implementasi pembiasaan tersebut sementara lembaga ini memiliki kekhasan pengembangan nilai agama moral selama di sekolah menjadi satu konsep yang ditekankan lebih banyak waktunya. Untuk mengatasi masalah tersebut guru menerapkan beragam media dan metode yang akan dilaksanakan dengan kolaborasi dengan orang tua menggunakan kegiatan yang menyenangkan. Penelitian ini dilakukan pada anak kelompok A di RA Kusuma Mulia Mojosari Kecamatan Kras Kabupaten Kediri sebanyak 15 anak. Metode penelitian akan digunakan studi kualitatif dimana teknik pengumpulan data dari observasi, wawancara dan dokumentasi. Analisis data dengan deskriptif kualitatif diperoleh hasil tentang implementasi pembelajaran nilai agama moral pada anak usia 4-5 tahun dengan menggunakan media interaktif hasil buatan guru memperoleh hasil peningkatan pada indikator pelaksanaan ibadah dan pengenalan waktu sholat 1 anak MB, 8 nak BSH dan 6 anak BSB. Rekomendasi yang dapat diberikan keterbatasan media yang dibuat guru sebaiknya dapat ditingkatkan dengan memanfaatkan lingkungan sekitar agar peningkatan aspek nilai agama moral juga dapat dilakukan seperti a spek lainnya.
\end{abstract}

Kata kunci: Implementasi, Nilai Agama dan Moral, Anak Usia Dini, Belajar dari Rumah

\begin{abstract}
Education from early childhood is hampered by the pandemic that has hit so that learning processes must be carried out from home. Collaboration between teachers and parents is needed in improving aspects of child development, one of which is related to the habituation of cultivating moral religious values. The problems faced by not all parents support the implementation of the habituation while this institution has a uniqueness in the development of moral religious values while in school into a concept that emphasizes more time. To overcome this problem the teacher applies a variety of media and methods that will be carried out in collaboration with parents using fun activities. This research was conducted on 15 children in group A in RA Kusuma Mulia Mojosari, Kras District, Kediri Regency. The research method will be used as a qualitative study where data collection techniques
\end{abstract}


from observation, interviews and documentation. Analysis of data using qualitative descriptive results obtained about the implementation of learning moral religious values in children aged 4-5 years using interactive media made by the teacher, which resulted in an increase in the indicators of the implementation of worship and the introduction of prayer times for 1 MB, 8 BSH children and 6 BSB children. Recommendations that can be given by the limitations of the media made by the teacher should be improved by making use of the surrounding environment so that aspects of religious moral values can also be done like other aspects.

Keywords: Implementation, Religious and Moral Values, Early Childhood, Learning from Home

\section{PENDAHULUAN}

Perkembangan terkait kondisi wabah yang terjadi akibat penyebaran virus Covid-19 masih terus berlangsung dan berdampak pada perpanjangan waktu belajar dari rumah juga terjadi lingkup lembaga PAUD. Beragam argumentasi yang beredar di kalangan masyarakat mengatakan kurang efektifnya pembelajaran secara online atau belajar dari rumah. Meskipun pemerintah sudah mengusahakan program di TVRI sebagai pendukung pengembangan program belajar dari rumah mulai tingkat PAUD sampai SLTA. Hal ini dengan tujuan guru, orang tua dan terutama siswa terbantu dalam pembelajaran. Survei yang dilakukan oleh Kemdikbud bersama UNICEF pada bulan April 2020 terkait program belajar dari rumah yang disiarkan oleh TVRI menghasilkan tingkat kesenangan dalam menonton TVRI adalah 7,8 skor untuk anak, 8,2 untuk skor orang tua dan tingkat kesenangan guru wilayah 3T hasilnya 7 dan di wilayah non-3T menghasilkan skor 7,5. TVRI sebagai saluran yang dipilih dalam memperoleh materi pembelajaran dengan paparan 20\% responden peserta didik meminta durasi waktu ditambahkan(Kemendikbud, 2020).

Hasil survei tersebut tentunya juga memiliki tujuan bahwa pemerintah khususnya Kementerian Pendidikan dan Kebudayaan terus memberikan pelayanan pendidikan dan terus memastikan pemenuhan hak anak agar mendapatkan layanan pendidikan selama masa darurat Covid-19. Lembaga PAUD harus terus menerapkan prinsip-prinsip pelaksanaan Belajar Dari Rumah yang berlandaskan pada SE Mendikbud No.4 Tahun 2020 dimana menegaskan utamakan keselamatan, kesehatan lahir batin secara keseluruhan dalam 
pelaksanaan BDR, dilakukan untuk memberikan pengalaman belajar bermakna bukan terbebani penuntasan kurikulum serta fokus pada pendidikan kecakapan hidup. Dimana peran pendidik dalam Belajar Dari Rumah harus memfasilitasi pembelajaran jarak jauh secara online maupun kombinasi keduanya sesuai dengan kondisi dan ketersediaan sarana pembelajaran. Guru harus mengoptimalkan seluruh aspek perkembangan anak meskipun dilakukan tanpa tatap muka melalui rancangan pembelajaran ditegaskan komunikasi efektif dengan orang tua (Kemdikbud and Kemdikbud, 2020).

Permasalahan tentu saja akan muncul apabila pembelajaran untuk anak usia dini dilakukan dengan tidak ada tatap muka, tetapi disini seorang guru harus tetap mempersiapkan seluruh kegiatan pembelajaran dalam keterbatasan agar menjadi pembelajaran bermakna bagi anak. Seperti penelitian yang dilakukan (Wulandari and Purwanta, 2020) dimana pembelajaran daring untuk anak PAUD merupakan hal baru sehingga perlu mengkaji terkait capaian perkembangan anak dipaparkan secara garis besar tingkat pencapaian perkembangan anak mengalami penurunan kecuali aspek seni dan hasil tertinggi pada sosial emosional perilaku prososial. Menyikapi hasil penelitian ini sebagai bahan kajian mendukung program rancangan pembelajaran yang dilakukan guru. Didukung oleh penelitian yang dilakukan (Pramana, 2020) metode pembelajaran yang memang mendadak ini memunculkan permasalahan dalam diri guru karena penguasaan kompetensi belum semua dapat diterapkan dalam penerapan teknologi. Perlu adanya kesabaran dan motivasi tinggi untuk dapat terus belajar dalam menemukan beragam solusi dan inovasi terkait ketercapaian proses belajar pada pengembangan aspek anak.

Aspek perkembangan yang menjadi masalah utama yang dihadapi lembaga PAUD RA Kusuma Mulia Mojosari Kecamatan Kras Kabupaten Kediri berdasarkan hasil evaluasi seluruh capaian perkembangan adalah pada nilai agama dan moral. Hal ini dikaitkan dengan program muatan pembelajaran di kurikulum lembaga menegaskan adanya muatan agama lebih banyak karena juga di wilayah naungan Kemenag. Muatan lokal tersebut menegaskan perilaku budi pekerti, sikap sopan santun, kemauan dalam pembiasaan menjalankan ajaran agama dalam kehidupan 
anak sehari-hari. Seperti pendapat Kohlberg, dalam (Lestariningrum, 2014) menegaskan bahwa capaian perkembangan moral pada anak usia dini berada di tingkat mendasar dimana pembentukan dalam sikap serta nilai moral tersebut memerlukan rangkaian proses yang tidak dalam waktu singkat tetapi harus terus diulang serta pembiasaan berkesinambungan dengan keteladanan. Dikuatkan hasil penelitian (Fitriyah, 2019) manakala sudah tumbuh rasa keagamaan pada diri seorang anak maka perlu adanya latihan sejak kecil dengan metode yang tepat sehingga keteladanan dalam seluruh pembelajaran mulai pembukaan, inti sampai penutup memuat contoh keteladanan yang diberikan guru. Hal ini tentu saja berbeda ketika dilakukan pembelajaran dari rumah dimana orang tua belum secara keseluruhan secara lengkap memberikan keteladanan seperti ketika guru di sekolah dengan tatap muka.

Media pembelajaran yang dipilih oleh RA Kusuma Mulia Mojosari Kecamatan Kras Kabupaten Kediri dalam pembelajaran dari rumah dengan menggunakan WhatsApp. Pemilihan media ini karena itu paling mudah dikuasai guru dan orang tua. menurut Sahidillah dan Miftahurrizqi, dalam (Sucipto Dwijo et al., 2020) menegaskan media WhatsApp memudahkan komunikasi terjalin karena bisa interaksi dengan diskusi melalui chating pesan dan mengirimkan materi pembelajaran tidak menghasilkan biaya mahal karena pemakaian menggunakan data internet bukan pulsa serta sebagian besar orang tua dapat menggunakan aplikasi tersebut. Terkait pengembangan nilai agama moral media WhatsApp juga digunakan oleh guru di lembaga PAUD RA Kusuma Mulia Mojosari dimana berdasarkan wawancara dengan kepala sekolah dan guru menegaskan adanya pembuatan video pembelajaran, panduan pembelajaran yang dikirimkan sekolah di group WhatsApp kemudian orang tua akan mengirimkan video, foto sebagai bukti sudah dilaksanakan di rumah oleh anak dengan pendampingan orang tua.

Setelah dilakukan rekapan penilaian dari hasil yang dikirimkan orang tua guru menganalisis masih kurangnya penanaman nilai-nilai hidup penekanan moral agama dimana pemahaman dan kesadaran pada diri anak masih belum muncul menjadi pembiasaan tetapi masih arahan guru dan orang tua saja. Pendidik tidak bisa melihat adanya kemampuan anak saat membedakan waktu beribadah dan 
juga perbuatan benar dan salah ketika kiriman hanya dari foto saja. Ditegaskan pendapat Sjarkawi, dalam (Retnosari, 2019) tujuan dalam pengembangan nilai agama moral anak usia 4-5 tahun membina terbentuknya adanya perilaku moral tidak hanya mengetahui aturan baik buruk tetapi harus menjadi perilaku melekat dalam diri anak. Perilaku melekat tersebut termasuk di dalamnya rutinitas melakukan kegiatan beribadah sesuai agama yang dianutnya. STPPA di Permendikbud 137 tahun 2014 untuk anak usia 4-5 tahun adalah: (1) mengetahui agama yang dianutnya, (2) meniru gerakan beribadah dengan urutan benar, (3) mengucap doa sebelum dan sesudah melakukan sesuatu, (4) mengenal perilaku baik/sopan dan buruk, (5) membiasakan diri berperilaku baik, (6) mengucapkan salam dan membalas salam.

Menindaklanjuti permasalahan yang terjadi maka guru di RA Kusuma Mulia Mojosari khususnya melakukan inovasi pembelajaran dalam mengembangkan nilai-nilai agama moral anak usia 4-5 tahun dengan membuat media sederhana yang menarik bagi anak sehingga dapat digunakan sebagai variasi pembelajaran selama di rumah dengan online WhatsApp. Media ini dipilih dengan tujuan dapat meningkatkan capaian perkembangan nilai agama dan moral. Oleh karena itu dalam penelitian yang dilakukan akan menjabarkan dan mendeskripsikan "Implementasi Pembelajaran Nilai Agama dan Moral Pada Anak Usia 4-5 Tahun Selama Belajar Dari Rumah". Hasil penelitian ini nantinya dapat memberikan gambaran bagi evaluasi yang dilakukan oleh lembaga dalam pemenuhan pembelajaran anak sesuai kekhasan kurikulum muatan lokal keagamaan. Perbedaan penelitian ini dengan penelitian yang dilakukan peneliti terdahulu yang dijabarkan sebelumnya peneliti akan menitikberatkan menggunakan media dibuat sendiri dan memilih indikator nilai agama moral menyebutkan urutan rukun islam dan menyebutkan nama-nama sholat 5 waktu. Fokus indikator ini menjadi pilihan peneliti karena dari hasil analisis capaian perkembangan NAM ini yang belum tercapai. 


\section{METODE}

Desain penelitian yang dipilih oleh peneliti dalam tujuan utama penelitian secara alamiah dan spesifikasi kondisi yang terjadi adalah desain kualitatif. Penelitian dilakukan pada bulan April-Mei 2020 bertempat di RA Kusuma Mulia Mojosari Kecamatan Kras, Kabupaten Kediri dengan subjek penelitian 15 anak usia 4-5 tahun di kelompok A. Teknik pengumpulan data yang digunakan triangulasi data dimana menggunakan observasi partisipatif, wawancara mendalam, dan dokumentasi untuk sumber data yang sama secara serempak. Analisis data berupa deskriptif kualitatif agar dapat mendeskripsikan seluruh hasil data dengan menarasikan dilengkapi dengan bukti-bukti yang diperoleh berupa catatan observasi dan wawancara, dokumentasi foto pembelajaran, dokumen perencanaan, dokumen penilain guru sehingga memudahkan dalam penjabaran hasil penelitian secara sistematis.

\section{HASIL DAN PEMBAHASAN}

Perencanaan Pembelajaran BDR Di RA Kusuma Mulia Mojosari Kecamatan Kras, Kabupaten Kediri

Pada saat kegiatan guru sudah mempersiapkan perencanaan dimana ada kegiatan pembukaan, inti dan penutup. Rancangan ini berisi kegiatan bermain dalam proses belajar mengacu pada karakteristik anak usia 4-5 tahun khususnya pengembangan nilai agama moral. Jabaran perencanaan tersebut adalah sebagai berikut:

Kegiatan Awal/Pembukaan

Guru fokus pada penyiapan anak baik dari segi psikis dan fisik agar semua memiliki kesiapan mengikuti kegiatan belajarnya. Saat awal di video call melalui online WhatsApp guru menunjukan media yang akan digunakan untuk memberikan ruang anak mengamati, memiliki ide inisiatif serta menggali pengalaman awal anak. Pembelajaran dengan media ini memilih indikator agar anak mampu menyebutkan rukun Islam selain dengan menyanyi juga ada media berupa iringan musik. Setelah itu dilanjutkan dengan menunjukan gerakan ibadah/sholat. Anak diberikan kesempatan menceritakan pengalaman di rumah 
tentang menjalankan sholat. Adapun bukti pendukung kegiatan awal/pembukaan ini adalah sebagai berikut:
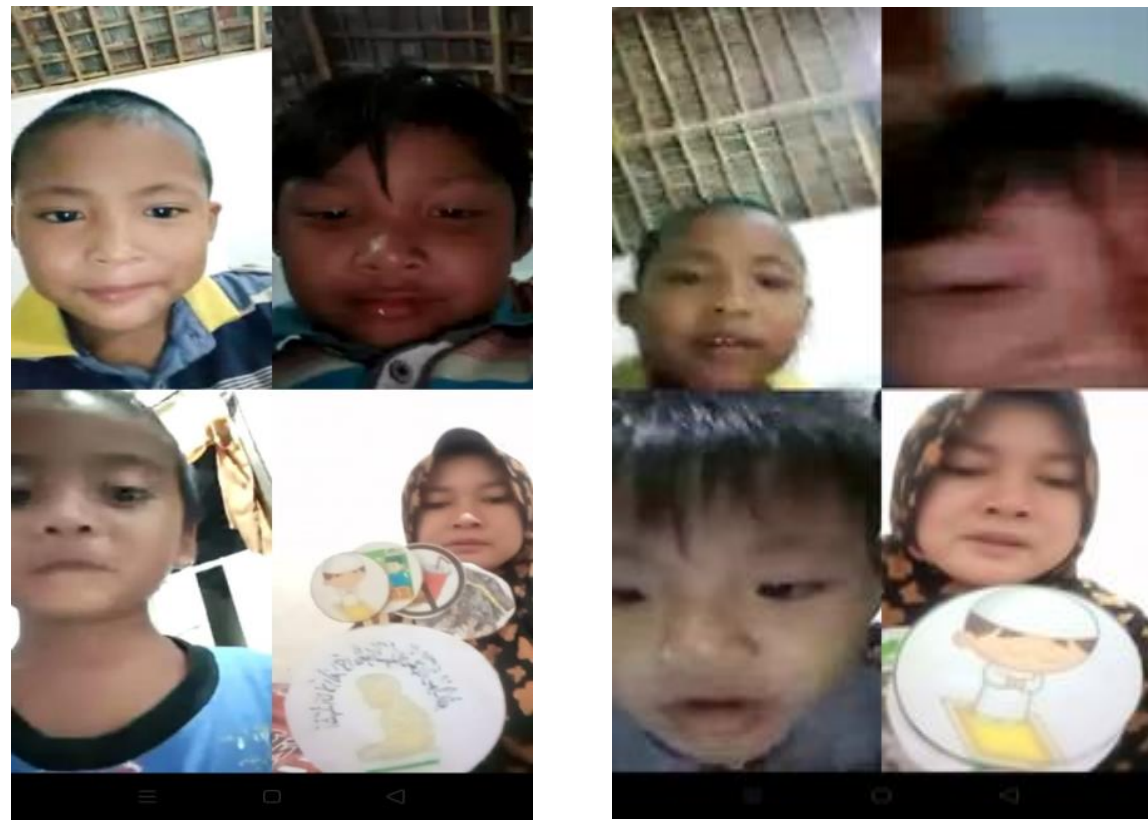

Gambar 1: Guru menunjukan media gambar urutan sholat saat kegiatan pembukaan

Kegiatan Inti

Guru akan memberikan pengalaman anak secara langsung dengan menunjukan kombinasi media supaya anak mendapat pengalaman saintifik dari mengamati gambar yang ada di media, mengajukan pertanyaan, mengumpulkan informasi yang disampaikan guru dan temannya, menalar sehingga konsep pengalaman semakin matang dalam memori anak. Guru selanjutnya memberikan kesempatan pada anak menyampaikan atau mengkomunikasikan dari apa yang sudah dilihat, didengar terkait materi yang diberikan. Guru memberikan tepuk tangan, reward ucapan langsung dengan kata-kata bagus, pintar supaya anak termotivasi.

Setelah penjelasan guru selesai anak dipesan agar mempraktekan apa yang sudah disampaikan guru menggunakan media kemudian diminta mendokumentasikan dan dikirim orang tua melalui WhatsApp group. Berikut dokumentasi kiriman orang tua sebagai penilaian yang dilakukan guru: 

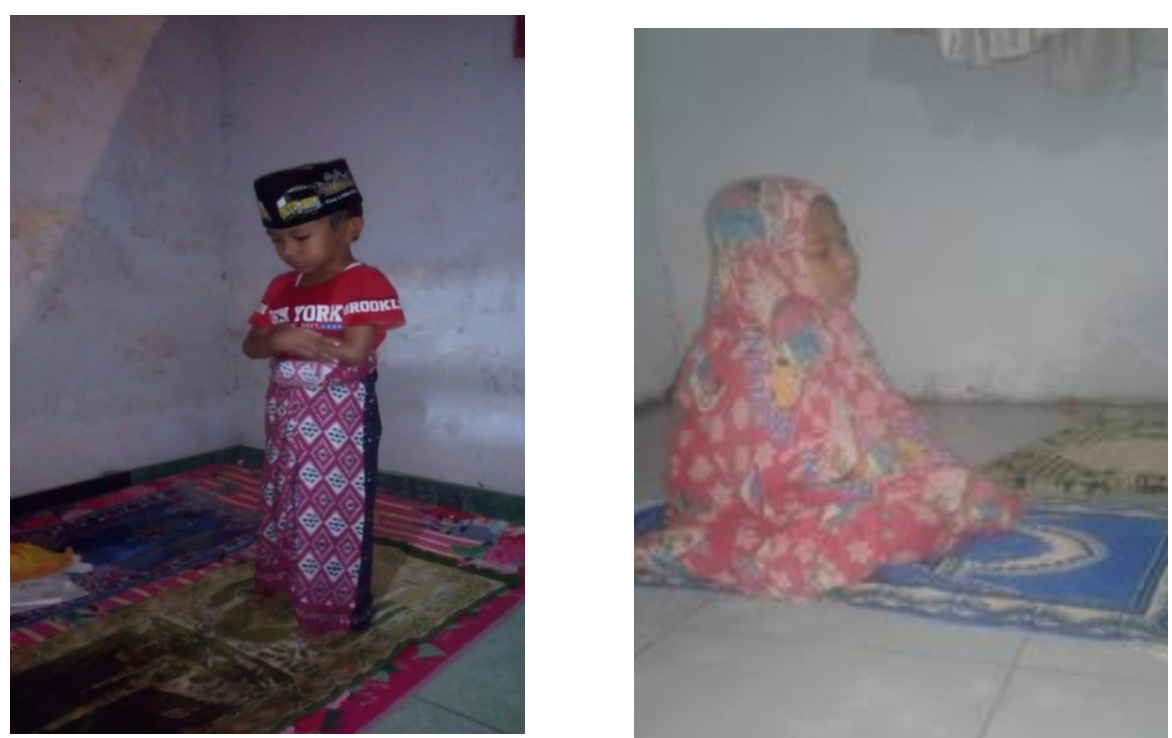

Gambar 2: Hasil penugasan anak yang dikirimkan orang tua

\section{Kegiatan Penutup}

Guru dalam kegiatan penutup melakukan cerita nasihat tentang perilaku baik dan buruk supaya anak lebih mendalam tentang pengembangan nilai agama moral anak. Setelah kegiatan penutup guru menunggu hasil kiriman dokumentasi orang tua kemudian dianalisis dan dilihat pencapaian perkembangan nilai agama moral anak diperoleh data dalam menyebutkan Rukun Islam, Anak yang masih membutuhkan bimbingan dalam menyebutkan Rukun Islam (Mulai Berkembang) ada 1 (satu) anak. Anak yang sudah mampu menyebutkan Rukun Islam tanpa bimbingan (Berkembang Sesuai Harapan) 5 terdapat anak. Untuk Anak Mampu menyebutkan Rukun Islam dengan benar sesuai dengan urutannya tanpa bimbingan (Berkembang Sangat Baik) terdapat 9 anak. Jadi dapat ditarik kesimpulan bahwa anak sudah berkembang sangat baik.

Dalam Menyebutkan nama-nama Sholat 5 Waktu, Anak mampu menyebutkan nama sholat 5 waktu dengan bimbingan (Mulai Berkembang) ada 1 (satu) anak. Capaian Anak mampu menyebutkan nama sholat 5 waktu tanpa bimbingan (Berkembang Sesuai Harapan) terdapat 4 (sebelas) anak. Anak mampu menyebutkan nama sholat 5 waktu dengan benar sesuai urutan tanpa bimbingan (Berkembang Sangat Baik) terdapat 10 (tiga) anak. Jadi dapat diamati bahwa anak berkembang sangat baik. 
Jika digambarkan dalam diagram batang capaian perkembangan anak aspek nilai agama moral sebagai berikut:
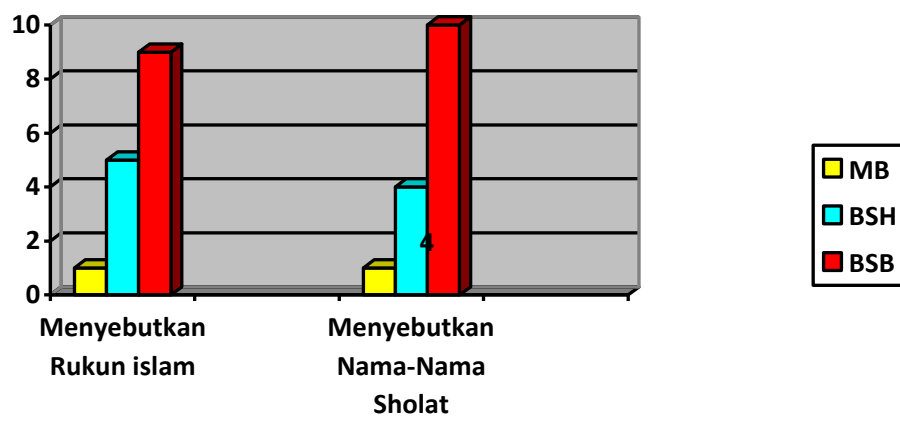

Gambar 3: Diagram Batang Capaian Perkembangan NAM Anak Usia 4-5 Tahun RA Kusuma Mulia Mojosari

Berdasarkan hasil penelitian yang sudah dipaparkan dapat dikatakan bahwa pembelajaran dalam pengembangan nilai agama dan moral selama belajar dari rumah menggunakan WhatsApp meskipun mengalami peningkatan dari hasil penilaian saat video call dengan tanya jawab langsung anak memiliki ketercapaian baik tetapi ketika hasil pengiriman orang tua masih perlu pengulangan dan pemahaman penjelasan guru kepada orang tua untuk memotivasi semua orang tua tuntas dalam mengirimkan tugas. Dibutuhkan pola interaksi juga antara anak dengan orang tua karena sifat anak yang masih membutuhkan bimbingan seperti penelitian yang dilakukan (Putro, Khamim, 2020) dimana pola interaksi ada dua arah yaitu interaksi langsung dan tidak langsung tetapi intinya selama pembelajaran dari rumah selama pandemic Covid-19 akan meningkatkan capaian perkembangan anak.

Selain itu terkait keteladanan pembiasaan juga ditekankan dalam penelitian (Nurjanah, 2018) yaitu perilaku yang akan ditampilkan dan diperbuat oleh orang tua akan menentukan bagaimana anak berperilaku moral dalam kehidupan beragama yang optimal. Ketika pendidik sudah memberikan materi dalam perencanaan pembelajaran disampaikan anak dengan antusias menjawab tetapi orang tua kurang memberikan teladan dan contoh tentu akan mempengaruhi capaian perkembangan juga. Dikuatkan dalam penelitian yang dilakukan 
(Syamsudin, 2017) bahwa tahapan nilai agama anak personal fungsional dimana ketika memenuhi rasa ingin tahu tentang sesuatu yang gaib dan membutuhkan pengalaman yang nyata dengan melihat praktek secara langsung. Saat anak unjuk kerja secara langsung menunjukan kompetensi capaian perkembangan sesuai pernyataan Mulyasa, dalam (Darmiyati, 2020) ketika anak melaksanakan berdasarkan kegiatan orang lain harus menga mati secara langsung yaitu membaca surat pendek, berdoa keseharian dilakukan secara rutin. Ini yang menjadi keterbatasan saat pembelajaran secara BDR karena orang tua hanya mengambil dokumentasi sesaat untuk dikirimkan dengan tidak melihat rutin anak melakukan kecuali di rumah ada ajakan contoh orang tua dilakukan bersama.

Kajian yang sudah diuraikan dalam pengembangan nilai agama moral tidaklah dalam waktu singkat, pengembangan diri agar melekat dalam karakter anak memerlukan waktu lama dan harus dilakukan berkesinambungan dan memerlukan strategi yang disetiap lembaga, guru maupun keluarga yang melibatkan orang tua sering dievaluasi untuk menemukan formula yang tepat dan sesuai kondisi masing-masing anak. Seperti strategi yang diuraikan (Inawati, 2017) yaitu meneliti dan mengamati hal ini sesuai sifat alamiah anak menggali pengalaman dengan mengamati dan melakukan proses saintifik itu masuk meneliti karena ada tahapannya. Guru dan orang tua harus merancang kegiatan yang lebih memberikan pengalaman dan prose pengamatan langsung tentunya dengan dilakukan cara menyenangkan melalui bermain dan tidak ada unsur paksaan. Rancangan pembelajaran harus disusun dengan baik karena perencanaan menurut (Lestariningrum, 2017) akan memegang peran upaya yang menentukan kegiatan yang akan dilakukan seorang guru dengan anak terutama saat BDR perencanaan menyesuaikan ketersediaan sarana yang dimiliki orang tua, jangan sampai orang tua merasa terbebani karena tidak bisa memenuhi pelaksanaan pembelajaran anak sesuai rencana guru yang terlalu berat.

\section{SIMPULAN}

Kesimpulan yang dapat dari pemaparan rumusan masalah dan tujuan penelitian yaitu implementasi pembelajaran nilai agama moral pada anak usia 4-5 
tahun dengan menggunakan media interaktif hasil buatan guru memperoleh hasil peningkatan pada indikator pelaksanaan ibadah dan pengenalan waktu sholat tentunya selama belajar dari rumah dilakukan kolaborasi efektif bersama orang tua dengan menggunakan dengan online WhatsApp. Rekomendasi diberikan melihat keterbatasan dari media yang dibuat guru sebaiknya dapat ditingkatkan dengan memanfaatkan lingkungan sekitar agar peningkatan aspek nilai agama moral di RA Kusuma Mulya Mojosari juga dapat dilakukan seperti aspek lainnya dan tidak kalah penting strategi mengimplementasikan saat BDR dibutuhkan komunikasi secara berkelanjutan dengan orang tua juga untuk capaian perkembangan yang lainnya.

\section{UCAPAN TERIMA KASIH}

Penulis secara khusus melalui karya ilmiah ini mengucapkan terima kasih kepada Kepala sekolah dan guru rekan sejawat di RA Kusuma Mulya Mojosari Kecamatan Kras Kabupaten Kediri yang sudah memberikan izin dan membantu proses penggalian data penelitian ini. Kepada Ibu Dr. Anik Lestariningrum, M.Pd dan Ibu Linda Dwiyanti, M.Pd yang berkenan kolaborasi pengolahan data dan membantu dalam penyelesaian artikel sampai bisa melakukan publikasi untuk pengalaman penulis selanjutnya motivasi berkarya.

\section{REFERENSI}

Anik Lestariningrum. 2014. "PENGARUH PENGGUNAAN MEDIA VCD TERHADAP NILAI-NILAI AGAMA DAN MORAL ANAK." PG PAUD Universitas Nusantara PGRI Kediri 8.

Anik Lestariningrum. 2017. " PERENCANAAN PEMBELAJARAN ANAK USIA DINI". http://repository.unpkediri.ac.id/2534/1/Buku\%20PERENCANAAN\%20PE MBELAJARAN\%20AUD_ISBN_9786026135544.pdf

Darmiyati, Darmiyati. 2020. "PENILAIAN UNJUK KERJA DALAM PENGEMBANGAN AGAMA DAN MORAL ANAK USIA DIN." Jurnal Pendidikan Kewarganegaraan 10(1):74. doi: 10.20527/kewarganegaraan.v10i1.8532.

Fitriyah, Fitriyah. 2019. "IMPLEMENTASI PENGEMBANGAN NILAI MORAL DAN 
AGAMA PADA ANAK USIA DINI MELALUI METODE KETELADANAN DI TK

AL-MUHSIN." Islamic EduKids 1(1):1-7. doi: 10.20414/iek.v1i1.1809.

Inawati, Asti. 2017. "Strategi Pengembangan Moral Dan Nilai Agama Untuk Anak Usia Dini | AL-ATHFAL: JURNAL PENDIDIKAN ANAK." Al-Athfal: Jurnal Pendidikan Anak 51-64. Retrieved (http://ejournal.uinsuka.ac.id/tarbiyah/index.php/alathfal/article/view/1422).

Kemdikbud, and pengelola web Kemdikbud. 2020. "Pedoman Penyelenggaraan Belajar Dari Rumah." Jakarta, 28 Mei 2020 8-9.

Kemendikbud. 2020. "Kemendikbud Rilis Hasil Survei Evaluasi Belajar Dari Rumah." Www.Kemendikbud.Go.Id $\quad 1 . \quad$ Retrieved (https://www.kemdikbud.go.id/main/blog/2020/05/kemendikbud-rilishasil-survei-evaluasi-belajar-dari-rumah)

Nurjanah, Siti. 2018. "PERKEMBANGAN NILAI AGAMA DAN MORAL (STPPA

TERCAPAI)." PARAMUROBI: JURNAL PENDIDIKAN AGAMA ISLAM 1(1):43-59. doi: 10.32699/paramurobi.v1i1.177.

Pramana, Cipta. 2020. "Pembelajaran Pendidikan Anak Usia Dini (PAUD) Dimasa Pandemi Covid-19." Indonesian Journal of Early Childhood: Jurnal Dunia Anak Usia Dini 2(2):116-24.

Putro, Khamim, dkk. 2020. "Pola Interaksi Anak Dan Orangtua Selama Kebijakan Pembelajaran Di Rumah." Fitrah: Journal of Islamic Education 1(1):124-40.

Retnosari, dikfa ardela. 2019. “Implementasi Pengembangan Nilai Agama Dan Moral Anak Usia 4-5 Tahun Di Ra Nurul Huda Semarang." Kemampuan Koneksi Matematis (Tinjauan Terhadap Pendekatan Pembelajaran Savi) 53(9):1689-99.

Sucipto Dwijo, Al-Qudus Nofiandri Eko, Sri Indarwati, Citra Amaliyah Saraswita Suwandini, and Siti Mustainah. 2020. "Penerapan Metode Pembelajaran Melalui Media WhatsApp Selama Pandemi COVID-19 Di RA Al-Qodir." JECED : Journal of Early Childhood Education and Development 2(2):124-31. doi: 10.15642/jeced.v2i2.840.

Syamsudin, Amir. 2017. "EVALUASI KETERCAPAIAN STANDAR ISI PERKEMBANGAN NILAI-NILAI AGAMA DAN MORAL ANAK USIA DINI PADA 
Maratus Solekah, Anik Lestariningrum, Linda Dwiyanti

Implementasi Pembelajaran...

SEMESTER GASAL 2016/2017 KB/TK PEDAGOGIA." Jurnal Pendidikan Anak 5(2). doi: 10.21831/jpa.v5i2.12374.

Wulandari, Hesti, and Edi Purwanta. 2020. "Pencapaian Perkembangan Anak Usia

Dini Di Taman Kanak-Kanak Selama Pembelajaran Daring Di Masa Pandemi Covid-19." Jurnal Obsesi : Jurnal Pendidikan Anak Usia Dini 5(1):452. doi: 10.31004/obsesi.v5i1.626. 